УДК 373.3.091.33:004.032.6

DOI:

Іван Василиків, кандидат педагогічних наук, старший викладач кафедри математики, інформатики та методики їх викладання у початковій школі, магістр факультету початкової та мистецької освіти Дрогобицького державного педагогічного університету імені Івана Франка

\title{
ОСНОВНІ ПРОБЛЕМИ ТА ШЛЯХИ ВПРОВАДЖЕННЯ МУЛЬТИМЕДІЙНИХ ТЕХНОЛОГІЙ В ПОЧАТКОВІЙ ШКОЛІ
}

У статті обтрунтовується специфіка використання мультимедійних технологій у процесі професійноі підготовки майбутнього вчителя початкової школи. У дослідженні припускається, щуо вирішальним різновидом застосовування мультимедійних засобів навчання є їх інтеграція в навчальний процес увиді ціккавих, динамічних, ігрових форм. Учні початкових класів опановують інноватику та одночасно поглиблюють свої знання з певних навчальних предметів комп 'ютерними засобами. Запровадження мультимедійних технологій в освітній процес є атрибутом гармонійного інтегрування різних видів інформації. Знання майбутнього вчителя початкової школи різноманітних видів мультимедійних технологій допускає педагогічно обтрунтовано застосовувати могутні дидактичні можливості мультимедіа у початковій ланці освіти.

Ключові слова: вчитель початкової школи; мультимедійні технологї; інформаційні технологї; презентаиія; Інтернет; анімація; Microsoft PowerPoint.

Jim. 10.

Ivan Vasylykiv, Ph.D.(Pedagogy), Senior Lecturer of the Mathematics, Informatics and Methods of Teaching in Elementary School Department, Master of Faculty of Elementary and Artistic Education Drohobych Ivan Franko State Pedagogical University

\section{MAIN PROBLEMS AND WAYS OF IMPLEMENTATION OF MULTIMEDIA TECHNOLOGIES IN THE ELEMENTARY SCHOOL}

The article substantiates the specifics of use of multimedia technologies in the process of training the future teacher of elementary school. In this article it is assumed that the decisive kind of application of multimedia learning tools is their integration into the learning process in the form of interesting, dynamic, and game forms. Elementary students learn innovation and at the same time deepen their knowledge of certain subjects by means of computers. The author admits that the introduction of multimedia technologies into the educational process is an attribute of the harmonious integration of various types of information. Knowledge of the future teacher of elementary school about various types of multimedia technologies allows pedagogically grounded use of powerful didactic capabilities of multimedia in the primary education.

Each time after the appearance of a new technical device, teachers are contemplating how to apply it to the solution of didactic tasks. So, by examining the natural features of learning resources, teachers formulate their didactic qualities and functions in the learning process.

The students study the surrounding world with the help of all sense organs. Still, the key sources of information acquisition are visual analyzers. It is no coincidence that $90 \%$ of all information students receive with the assistance of the view, and 10\% - with the help of hearing. "It's better to see once than to hear 100 times" - so it's a true proverb.

In recent years, copying and video equipment, musical centers, a new generation of diagonal projectors and graphic projectors have been developing and expanding intensively in schools. The number of modern computer rooms in schools is increasing. Effective use of information technology in the educational process helps to successfully address the challenges faced by the school and the teacher.

Keywords: a teacher of elementary school; multimedia technologies; Information Technology; presentation; Internet; animation; Microsoft PowerPoint.

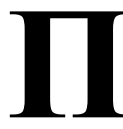

остановка проблеми у загальному вигляді та їі зв'язок із важливими науковими чи практичними завданнями. Актуальність проблеми полягає в тому, що нині в умовах великих перемін у громадському, економічному та політичному існуванні в Україні виникла проблема докорінної перебудови у галузі освіти та виховання, мета якої
- продукувати конкурентно вдалу, творчу особистість, яка придатна до самовизначення, до самореалізації та самовдосконалення. Оскільки навчання у сьогочасній школі має покривати найкращі передумови для самореалізації особистості школяра, виявлення усіх закладених

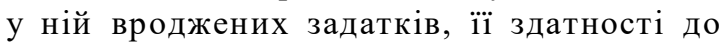
незалежності, відповідальності й творчості. 


\section{ОСНОВНІПРОБЛЕМИ ТАШЛЯХИ ВПРОВАДЖЕННЯМУЛЬТИМЕДІЙНИХ ТЕХНОЛОГЙ В ПОЧАТКОВІЙ ШКОЛІ}

Вагомим чинником, що розкриває характер зламів у системі освіти, $\epsilon$ науково-технічний прогрес, який на істинному періоді зростання нереальний без інформаційних технологій. На нинішньому періоді зростання інформаційного суспільства мультимедійні технології є не просто неминучими, але й звичайними прийомами (рекламні монітори, автомобільні акустичні та навігаційні системи, домашні кінотеатри й кінопалаци). Опанування підростаючим поколінням навиками вільного користування засобами мультимедіа в побуті, основуючись ще 3 ранішнього дитинства, виходить чимраз звиклим. Наглядаючи за сучасними дітьми бачимо, що учні початкової школи інтуїтивно вловлюють норми володіння мультимедійними технологіями для реалізації особистих цілей. Легкість у застосовуванні зумовлена новітнім дружнім інтерфейсом мультимедіа: присутність стандартизованих відміток, інтерактивної системи підказок, “штучного інтелекту” мультимедіа.

Аналіз останніх досліджень і публікацій, у яких започатковано розв'язання проблеми. Теоретичну основу дослідження склали роботи 3 питань сучасних педагогічних технологій (О. Пометун, Л. Пироженко, Л. Масол, Л. Аристова). Дослідження вчених і педагогівпрактиків (Л. Масол, І. Красильникова, І. Гутчина, Р. Петеліна, С. Полозова) аргументовано демонструють про те, що застосування IT під час навчально-виховного процесу має такі визначальні привілеї: відбувається диференціація навчального процесу; зростає контроль за навчальною діяльністю учнів і забезпечується на цій основі зворотний зв'язок; появляються умови для підняття рівня інтересу учнів у навчальній діяльності завдяки внесенню деталей новизни.

Мета статті. Акцентувати вагомість застосування мультимедійних технологій у початковій школі в умовах компетентнісного підходу.

Виклад основного матеріалу. На початку XXI століття школи в Україні уже посідають вдосталь високий ступінь комп'ютеризації як у містах, так і в селах. Абсолютно можливо, що урок, здійснений за сприянням мультимедійного проектора, електронної дошки або комп'ютера, має добротні привілеї над традиційно проведеним заняттям. Шкільна освіта цілеспрямована на розвиток людини нового інформаційного суспільства.

Знедавна основне місце у викладанні предметів займають звичні засоби - дошка, крейда та друковані джерела (підручники, зошити 3 друкованою основою). Завдяки ж застосуванню
IT навчальне середовище можна вільно поповнити відео, звуком, анімацією. Усе це втілює вагомий вплив на чуттєве поле молодшого школяра, допомагаючи підняттю пізнавальної активності, підняттю зацікавленості до предмета та навчання загалом, активізації навчальної роботи учнів. Тому молодші школярі віднині приготовані до роботи з IT: вони знають, що таке комп'ютер, у більшості випадків можуть його застосовувати, у них неприсутній психологічний бар'єр: діти не побоюються, що зламається машина, не вистачить знань осилити з нею тощо. Все-таки, машина без людського чинника залишається розумною забавкою. Нині вже можливо, що вчитель, який проводить заняття за сприянням мультимедійного проектора, електронної дошки та комп’ютера, застосовує на уроці та під час підготовки до нього ресурси Інтернет, має добротні плюси перед колегою, який застосовує на уроці “крейдяну технологію”. Виховання учнів в школі має бути цілеспрямоване на розвиток людини нинішнього інформаційного суспільства, $\mathrm{i}$ школа має вчити застосовувати необмеженим джерелом інформації- Інтернетом, та принаймні, попробувати навчити дитину відділяти що є добре і корисне від злого [5].

Мультимедіа допомагає створенню умов для організації роботи напрямом єднання навчального матеріалу і забезпечення його благополучного сприйняття 3 підключенням розбіжних видів пам'яті - зорової, слухової, емоційної та ін.

Із використання мультимедійних засобів на уроці ми дістаємо дві основні привілеї - якісну і кількісну. Якісно нові переваги доведені, якщо зрівняти словесні описи 3 безпосереднім аудіовізуальним баченням. Кількісні переваги позначатимуться у тому, що мультимедіасередовище вельми вище за інформаційною щільністю. Як звісно, одна сторінка тексту включає інформацію, яку вчитель промовляє орієнтовно за $1-2$ хвилини. За цей самий період часу повноекранне відео несе інформації у сотні разів більше [9].

Мультимедійні матеріали, що застосовуються у практиці початкового навчання, можна поділити на такі різновиди:

1) мультимедіа-презентації;

2) мультимедіа-тренажери;

3) електронні навчальні комплекти (електронні підручники, хрестоматії, енциклопедії, атласи та ін.);

4) мультимедійні ресурси Інтернету.

Під мультимедіа-презентацією ми розуміємо логічно пов'язану систематичність слайдів, поєднану однією тематикою і загальним правилом 


\section{ОСНОВНІПРОБЛЕМИ ТАШЛЯХИ ВПРОВАДЖЕННЯМУЛЬТИМЕДІЙНИХ ТЕХНОЛОГЙ В ПОЧАТКОВІЙ ШКОЛІ}

оформлення. 3 їі підтримкою вчитель може не тільки ознайомити матеріал 3 теми, яка вивчається, а й поглиблювати у школярів логічне та алгоритмічне мислення, адже всі презентації будуються за єдиною логічною схемою. Мультимедіа-презентація дає здатність виробляти взаємозв'язок з об'єктами або процесами, що відбиватимуться на екрані, імітувати реальність.

Застосовування мультимедіа-тренажерів дає шанс учням тренуватися у відпрацюванні всіляких прийомів навчальних дій. Використовуються навчальні ігри під час узагальнення та систематизації знань. Нині окреслено немало багатоманітних тренажерів, зокрема, “Дитячий тренажер грамотності”, “Аліса вивчає українську мову”, “Українська абетка”, “Буквар Котигорошко”, "Грамотійка та іiі друзі”, "Бджілка Жу-Жу. Зачаровані числа”, “Таблиця множення - Юні водії" та ін. Але можна зробити тренажер самотужки за сприянням програми Microsoft PowerPoint. Гра-тренажер породжують у дитини мотиваційну та інтелектуальну готовність застосування комп'ютерних прийомів для виконання своєї діяльності. Ігрова робота - це багатоскладовий і дійовий хід, побудова якого залучає інтелектуальну, пізнавальну, пошукову, проектну та інші конфігурації прояву творчої активності.

Ю. Казаков, виучуючи педагогічні умови використання медіа-освіти в ході професійної підготовки майбутніх учителів початкових класів, зазначає, що термін “мультимедіа" часто застосовують для відмітки джерел інформації, які дозволяють берегти величезні обсяги даних i покривають досить швидкий доступ до них, наприклад CD - Compact Disk, DVD - Digital Versatilel Video Disk. Інакшими словами, під терміном “мультимедіа" можна розуміти й мультимедійнупрограму-оболонку, й продукт, який винайдено на базі мультимедійної технології, й комп'ютерне забезпечення. Водночас, мультимедіа - це частковий вид комп'ютерної технології, який єднає в собі звичну статичну візуальну інформацію (текст, графіку), так і динамічну - мовлення, музика, відеофрагменти, анімація) [3].

Обладнування закладів вищої освіти засобами інформаційних технологій сьогодні обіймає вагоме місце в інформатизації вищої освіти. Це визначає створення: мультимедійних комп'ютерних класів; мережного сполучення між структурними одиницями навчального закладу; виходу до мережі Internet; навчальних мультимедійних продуктів; підготовка викладачів для використання можливостей інформаційнотелекомунікаційних технологій унавчальних цілях $[2,31]$

B. Імбер допускає, що використання мультимедійних засобів навчання у підготовці майбутнього вчителя початкових класів виступитиме у значній ролі. Приміром, мультимедійне навчання для майбутніх учителів початкових класів забезпечує:

- збільшення джерел отримання та представлення нової інформації;

- розвиток самостійності та креативного мислення в ході виготовлення особистих мультимедійних проектів;

- пришвидшення темпів навчання;

- забезпечення особистого підходу у навчанні $[2,59]$

Оволодіння вчителем початкових класів технологією мультимедіа відбувається безпосередньою роботою, яка присвоює три компоненти:

- навчальний (вміння роботи 3 програмою Microsoft PowerPoint);

- методичний (вироблення власної методики проведення уроків 3 використанням можливостей “мультимедійних технологій”);

- професійний (перекваліфікація, підготовка вчителів зі знаннями застосування "мультимедійних технологій”) $[2,63]$.

Мультимедіа посідають вагоме місце для застосовування в навчальному процесі.

Американські науковці Флетчер, Дейл і Нельсон проаналізували традиційні форми навчання і мультимедійні засоби викладання. Втілюючи власні дослідження самостійно один від одного, науковці прийшли до висновку про те, що мультимедійні навчальні програми посідають значне місце перед звичайними, традиційними [6].

Розвідка українськими ученими (П. Гороль [1], Р. Гуревич, Л. Конишевський, О. Шестопалюк) вказує значні шанси технології мультимедіа, приміром, науковці наводять, що система "вухомозок” пропускає за секунду 50 одиниць інформації, а система “окомозок" - 500 [1].

Ціну ваги мультимедійних технологій реалізовано польським ученим Г. Кєдровічем, котрий підкреслює: “...навчання дає тим кращі результати, чим багатшим є багатоканальний спектр потоку інформації між окремими елементами комунікації” [4]. Аргументом цього є розвідка інституту “Свролінгвіст” (Голандія), що більшість людей запам'ятовує 5\% почутого і $20 \%$ побаченого. Рівночасне застосовування аудіо і відеоінформації збільшує запам' ятовування до 40 $-50 \%[8]$.

Даний контекст заслуговує на увагу розвідки, 


\section{ОСНОВНІПРОБЛЕМИ ТАШЛЯХИ ВПРОВАДЖЕННЯМУЛЬТИМЕДЙНИХ ТЕХНОЛОГЙ В ПОЧАТКОВІЙ ШКОЛ}

здійсненої Я. Гайдою (J. Gajda), С. Ющиком (S. Juszczyk), Б. Сємєніцкі (B. Siemieniecki), K. Вента (K. Wenta), які викрили, що використання мультимедіа в освіті допомагає підняттю ефективності навчання відносно 3 звичним навчанням, наприклад: дієвість навчання вища на $56 \%$; розуміння теми виростає на 50 $60 \%$; непорозуміння при передачі знання скоротилися на 20 - 40\%; економія часу на 38 $70 \%$.

Отже, розгляд наукових праць вітчизняних та зарубіжних учених засвідчує, що вчені всіляко доводять до перспектив застосовування їх мультимедійних технологій у навчальному процесі. За допомогою багатосередовищним перспективам технології мультимедіа застосовуються у різноманітних ділянках роботи людей, вирішальною поміж яких є освіта.

Висновки 3 дослідження і перспективи подальших розвідок у цьому напрямі. Запровадження компетентнісного підходу в діяльність початкової освіти може бути більш ефективним, якщо у майбутніх учителів буватимуть сформовані теоретичні знання про перспективи мультимедіа-технологій та про методику становлення на їхньомугрунті обставин, у котрих учень примудриться відпрацьовувати навички роботи, визначені компетенцією. Попри найвищу ефективність вбачатимуть індивідуальноорієнтовані опрацювання і технології, що обіймають у собі мультимедіа-програми, адаптовані особистій освітній манері і потреб навчання; визначають активізацію функції учнів в освітніх процесах за рахунок багатофункціональності та різноманіття використаних мультимедіа.

Наукові джерела та досвід учителів-новаторів демонструють те, що школярі мають високий ступінь готовності (мотиваційний, пізнавальний, емоційно-вольовий), а вчителі мають чітко сформовані потреби і об'єктивні шанси для застосовування мультимедіа у навчальному колі. Питання доцільної побудови методичної системи навчання 3 застосовуванням мультимедіа $\epsilon$ далекосяжною, а іii розв'язання допускає вбезпечити навчання учнів початкової школи універсальними способами для формування вирішальних компетенцій.

\section{ЛІТЕРАТУРА}

1. Гороль П.К., Гуревич Р.С., Коношевський Л.Л., Шестопалюк О.В. Сучасні інформаційні засоби навчання. - Вінниця: ВДПУ імені М.Коцюбинського, 2004. -535 c., c. 8 .

2. Імбер В. І. Педагогічні умови застосування мультимедійних засобів навчання у підготовці майбутнього вчителя початкових класів: дис. ... канд. пед. наук: 13.00.04 / Імбер Вікторія Іванівна. - Вінниця, 2008. $-238 \mathrm{c}$

3. Казаков Ю.М. Педагогічні умови застосування медіаосвіти в процесі професійної підготовки майбугніх учителів: автореф. на здобугтя наук. ступеня канд. пед. наук. : 13.00.04 "Теорія та методика професійної освіти" / Ю. М. Казаков. - Луганськ, 2007. - 20 с., с. 9 - 19.

4. Кєдровіч Г. Оцінка дидактичної придатності вибраних мультимедійних програм / Гжегош Кєдровіч // Педагогіка і психологія професійної освіти. - 2000. №2. - C. $83-88$., c. 85.

5. Климова К. Я. Теорія і практика формування мовно-комунікативної професійної компетентності студентів нефілологічних спеціальностей педагогічних університетів: Монографія / К. Я. Климова. - Житомир: "Руга", 2010.-560 c.

6. Мультимедіа та мультимедійні системи: Конспект лекцій для студентів спеціальності “Програмне забезпечення автоматизованих систем. / Уклад. С. С. Забара, О. П. Цурін. - К.: Видавництво Університету "Україна", $2003-154$ c., c. 48.

7. Науменко Г. Г., Науменко О. М. Підготовка вчителя в умовах застосування ІКТ // Комп'ютер у школі та сім'і / Г. Г. Науменко, О. М. Науменко. -2008. - № 8. - С. 6 10.

8. Осин А. Мультимедиа в образовании / А. Осин / / Шкільна бібліотека плюс. -2005. - № 9. - С. 11-24., с. 15.

9. Смолянинова О.Г. Мультимедиа в образовании (теоретические основы и методика использования): Монографія / О.Г. Смолянинова - Красноярск: Изд. КрасГУ, 2002. - 300 с., с.67.

10. Шишка I. В. Використання мультимедійних засобів навчання на уроках в початкових класах: Посібник / I. В. Шишка - Шевченкове, 2013. - 250 с. Електронний ресурс. Режим доступу: www.yrok.net.ua/ _ld/21/2182.doc. Дата звернення: 22. 06. 2017.

\section{REFERENCES}

1. Horol, P.K., Hurevych, R.S., Konoshevskyi, L.L. \& Shestopaliuk, O.V. (2004). Suchasni informatsiini zasoby navchannia [Modern informational means of studying]. Vinnytsia: VDPU imeni M.Kotsiubynskoho, 535 p., p.8. [in Ukrainian].

2. Imber, V. I. (2008). Pedahohichni umovy zastosuvannia multymediinykh zasobiv navchannia u pidhotovtsi maibutnoho vchytelia pochatkovykh klasiv [Pedagogical conditions of use of multimedia means of teaching in the preparation of the future teacher of elementary school]. Candidate's thesis. Vinnytsia, 238 p. [in Ukrainian].

3. Kazakov, Yu. M. (2007). Pedahohichni umovy zastosuvannia mediaosvity $\mathrm{v}$ protsesi profesiinoi pidhotovky maibutnikh uchyteliv [Pedagogical conditions of the use of media education in the process of training of future teachers]. Extended abstract of candidate's thesis. Luhansk, 20 p., pp. 9 - 19. [in Ukrainian].

4. Kiedrovich, H. (2000). Otsinka dydaktychnoi prydatnosti vybranykh multymediinykh prohram [Estimation of the didactic suitability of selected multimedia programs]. Pedagogy and psychology of 
vocational education. No.2, pp. 83 - 88,, p. 85. [in Ukrainian].

5. Klymova, K. Ya. (2010). Teoriia i praktyka formuvannia movno-komunikatyvnoi profesiinoi kompetentnosti studentiv nefilolohichnykh spetsialnostei pedahohichnykh universytetiv [Theory and practice of formation of language and communicative professional competence of students of non-philological specialties of pedagogical universities]. Zhytomyr: 1111 "Ruta", 560 p. [in Ukrainian].

6. Zabara, S. S. \& Tsurin, O. P. (Ed.). (2003). Multymedia ta multymediini systemy: Konspekt lektsii dlia studentiv spetsialnosti "Prohramne zabezpechennia avtomatyzovanykh system [Multimedia and multimedia systems: A summary of lectures for students of the specialty "Software of automated systems"]. Kyiv: Vydavnytstvo Universytetu "Ukraina", 154 p., p. 48. [in Ukrainian].
7. Naumenko, H. H. \& Naumenko, O. M. (2008). Pidhotovka vchytelia $\mathrm{v}$ umovakh zastosuvannia IKT [Teacher's Training in the Use of ICT]. Computer at school and family, No. 8, pp. 6-10. [in Ukrainian].

8. Osyn, A. (2005). Multymedya v obrazovanyy [Multimedia in Education]. School library plus. No. 9, pp. 11-24., p. 15. [in Russian].

9. Smolyaninova, O.G. (2002). Multimedia v obrazovanii (teoreticheskie osnovy $i$ metodika ispolzovaniya) [Multimedia in education (the theoretical foundations and method of use]. Krasnoyarsk: Izd. KrasGU, 300 p., p.67. [in Russian].

10. Shyshka, I. V. (2013). Vykorystannia multymediinykh zasobiv navchannia na urokakh v pochatkovykh klasakh: Posibnyk [Using Multimedia Learning Tools at Elementary Classes: A Guide]. Shevchenkove, 250 p. [Electronic resource]. Available at: www.yrok.net.ua/_ld/21/2182.doc. (accessed 22.06. 2017). [in Ukrainian].

Стаття надійшла до редакції 21.12.2018

УДК 378.147.61/811.11

DOI:

Nataliya Tymoshchuk, Ph.D.(Philology), Associate Professor of the Ukrainian and Foreign Languages Department Vinnytsya National Agrarian University

\section{PROFESSIONALLY-ORIENTED TEACHING OF A FOREIGN LANGUAGE AT THE AGRARIAN UNIVERSITY}

The article considers peculiarities of professionally-oriented teaching of a foreign language at the agrarian university. Nowadays, the problems of enhancing professional competence of future professionals, their training for future activities in the current socio-economic conditions are extremely urgent. Exploration of higher education standards applied in recent years reveals a significant increase in the requirements for foreign language knowledge gained by non-linguistic students. In terms of intensive cooperation with foreign partners, it is extremely important to be able to communicate with foreign colleagues. Therefore, one of the core elements of students ' professional competence is the ability to speak a foreign language at the level that is accessible for perception by a recipient. That is why teaching a foreign language as a means of communication in the future professional activity should be a priority goal of teachers. Thus, the formation of foreign language professional communicative competence of future agrarian specialist required for the use and analysis of foreign language information and data is an actual goal of the modern high school. The aim of the research is to offer ways to improve the quality of the professional training of agricultural students in the process of mastering foreign languages. It should be noted that the formation of professional skills of students in the process of learning foreign languages will be effective if the current level of personal development is taken into consideration as well as the prospects for professional development, possible communication difficulties are anticipated and prevented by means of adequate tasks for group and individual work, systematic activities aimed at developing motivation and reasoning of joint decisions are organized.

Keywords: professional qualities; foreign language professional communicative activity; communicative competence; competences.

Ref. 10.

Наталія Тимощук, кандидат філологічних наук, доиент кафедри украӥнської та іноземних мов Вінницького національного аграрного університету

\section{ПРОФЕСІЙНО СПРЯМОВАНЕ НАВЧАННЯ ІНОЗЕМНІЙ МОВІ В АГРАРНОМУ УНIВЕРСИТЕТI}

У статті розглянуто особливості професійно-спрямованого навчання іноземній мові в аграрному закладі вищої освіти. Одним із найважливіших елементів професійної компетентності майбутніх фахівців є володіння іноземною мовою на рівні, доступному для сприйняття реципієнтом. Нами досліджено особливості 